\title{
Absence of Polar Effect of Frameshift Mutations in the $E$ Gene of the Escherichia coli argECBH Cluster
}

\author{
By S. BAUMBERG AND E. ASHCROFT* \\ Department of Genetics, University of Leeds, Leeds, LS $29 J T$
}

(Accepted for publication I4 September 1971)

\begin{abstract}
SUMMAR Y
Four arginine auxotrophs have been obtained in Escherichia coli KI 2 following treatment with the acridine half-mustard ICR I9I. Their properties show that they carry mutations in the $E$ gene of the $\arg E C B H$ cluster, and their reversion patterns indicate that these mutations are frameshifts. The mutations exert no polar effect on the expression of the $\arg C, B$ and $H$ genes. These results accord with earlier suggestions that $E$ is not transcribed on to the same messenger RNA molecule as $C, B$ and $H$.
\end{abstract}

\section{INTRODUCTION}

The nine structural genes and single regulator gene for the enzymes mediating arginine synthesis from glutamate in Escherichia coli KI2 (Fig. I) constitute one of the best-known systems of functionally related genes showing incomplete clustering (Maas, I96I ; Glansdorff, Sand \& Verhoef, 1967; Taylor, 1970). Four of these genes, $\arg B, C, E$ and $H$, appear to be contiguous; the gene order (Glansdorff, 1965) is $E-C-B-H$ (Fig. I). Genes $\arg B, C, E$ and $H$ code respectively for $N$-acetyl- $\gamma$-glutamokinase, $N$-acetylglutamic $\gamma$-semialdehyde dehydrogenase, acetylornithinase, and argininosuccinase (Fig. I); we shall call the enzymes $\mathrm{B}, \mathrm{C}, \mathrm{E}$ and $\mathrm{H}$.

The functional organization of this cluster has still not been completely elucidated. The observation of polar effects of certain nonsense and deletion (presumably frameshift) mutations in $\arg C$ and $B$ on the expression of $B$ and $H$ and of $H$ respectively (Cunin, Elseviers, Sand, Freundlich \& Glansdorff, I969) and of a $C$ mutation, probably frameshift, on the expression of $B$ and $H$ (Vogel, Baumberg, Bacon, Jones, Unger \& Vogel, 1967; Ashcroft, 1970) suggests that $C, B$ and $H$ are transcribed on to a single polycistronic messenger RNA molecule in the direction $\overrightarrow{\mathrm{CBH}}$. Cunin et al. (1969) reported that of five amber argE mutations isolated, none showed a polar effect on the expression of $C, B$ and $H$, suggesting that $E$ is not part of the $C B H$ operon (i.e. is not transcribed on to the same messenger as the latter three genes). The properties of a mutant carrying a deletion probably spanning the $E-C$ boundary suggest (Elseviers, Cunin \& Glansdorff, 1969) that $\arg E$ is transcribed on to a separate messenger in the same direction as $C, B$ and $H$, but later work (N. Glansdorff \& R. Cunin, personal communication; Ashcroft, 1970) casts doubt on this interpretation. Frameshift mutations in an operon usually exert a polar effect on promoter-distal genes (Martin, Whitfield, Berkowitz \& Voll, 1966), probably due to the generation of terminator codons in the phase-shifted region of the messenger (Martin, 1967). Such mutations are readily induced in Escherichia coli by the acridine half-mustard ICR-I9I (3-chloro-7methoxy-9-[3-chloroethyl-aminopropyl-amino]acridine) (Berger, Brammar \& Yanofsky, I968).

\footnotetext{
* Present address: St Timothy's Mission, Pond Inlet, Baffin Island, N.W.T., Canada.
} 

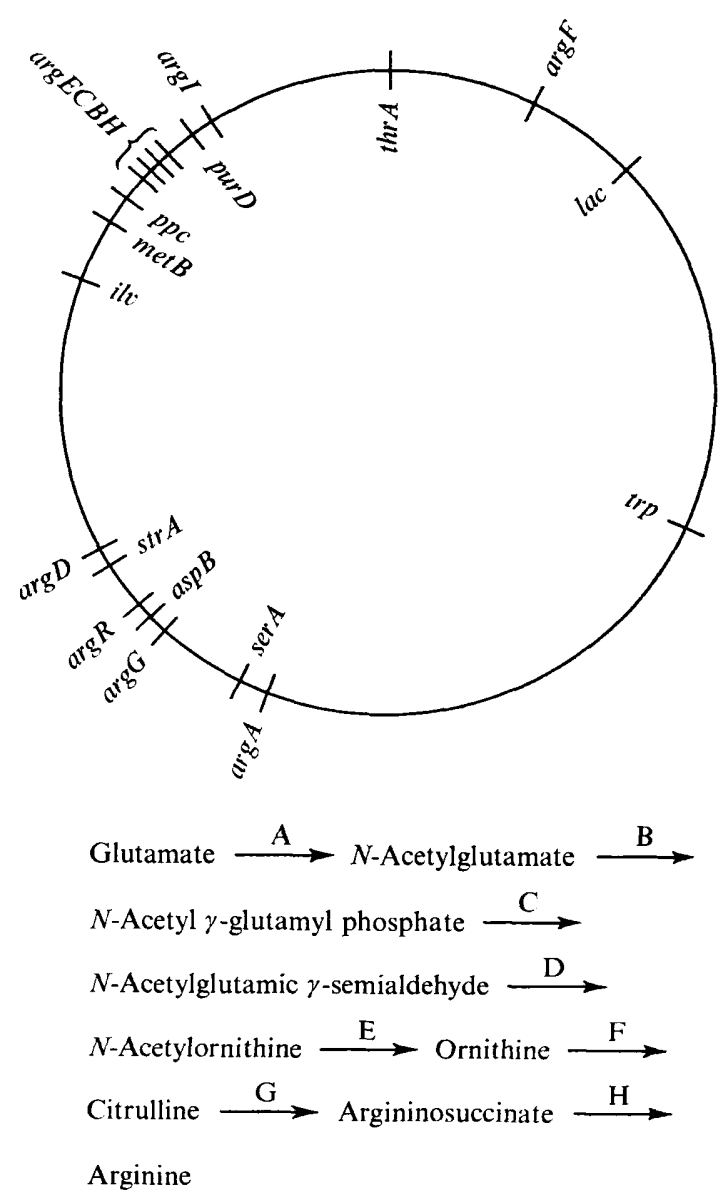

Fig. I. Genes and enzymes of arginine synthesis in Escherichia coli $\mathrm{K} 12$. The gene $\arg R$ is a regulator gene, mutations in which permit arginine enzyme synthesis at elevated rates unaffected by the presence of arginine.

We report here the isolation of four $\arg E$ mutants following treatment with this mutagen: their reversion patterns indicate that they carry frameshifts. No polar effect on the expression of $\arg C, B$ or $H$ could be detected, supporting the conclusion of Cunin et al. (1969) that $E$ is transcribed on to one messenger and $C, B$ and $H$ on to another.

\section{METHODS}

Bacterial strains (all derivatives of Escherichia coli $\mathrm{KI} 2$ ) are listed in Table $\mathbf{I}$.

Media and growth of cultures. Minimal media and L-broth have been described (Baumberg, 1970). Nutrient broth was Oxoid no. 2. Overnight nutrient broth cultures were grown from single colonies on a nutrient agar plate. Strains for lysis by $\mathrm{P}_{\mathrm{I}} k c$ and recipient cultures in transductions were grown in L-broth.

Preparation of cell extracts and enzyme assays. To grow up cultures for enzyme assay, $0.1 \mathrm{ml}$. of an overnight broth culture was inoculated into minimal salts-glucose medium ( $10 \mathrm{ml}$.) supplemented with amino acids as required and grown overnight at $37^{\circ}$ on an orbital incubator. The minimal medium overnight culture was diluted 20- to Ioo-fold in identical 
medium, and incubation was continued under the same conditions. Bacterial growth was followed as o.D. at $660 \mathrm{~nm}$., a correction being applied for the nonlinear relationship between O.D. and bacterial mass for O.D.'s above about 0.3 .

Cells were harvested at $0 . D$. ( $660 \mathrm{~nm}$.) 0.6 to $0 \cdot 7$, and centrifuged at $10,000 \mathrm{~g}$ for $10 \mathrm{~min}$. at $4^{\circ}$. The cells were resuspended in 0.1 M-potassium phosphate buffer, $\mathrm{pH} 7$, containing reduced glutathione at $1^{-3} \mathrm{M}$, and broken in an MSE 100 watt ultrasonic disintegrator operating at maximum amplitude for $20 \mathrm{sec}$. $\left(0^{\circ}\right)$. Extracts were centrifuged at $38,000 \mathrm{~g}$ for I 5 min. at $4^{\circ}$. Enzyme B was assayed immediately; if the other assays were to be performed later, extracts were stored at $-20^{\circ}$.

Enzyme B was assayed by the method of Baich \& Vogel (1962), with the following modifications to the reaction mixture: $\alpha-N$-acetyl-L-glutamic acid, adjusted to $\mathrm{pH} 7.4$ with $\mathrm{NaOH}$, $30 \mu$ moles; $\mathrm{MgCl}_{2}$, I5 $\mu$ moles; ATP, $6 \mu$ moles; hydroxylammonium chloride, adjusted to $\mathrm{pH}_{7} \cdot 4$ with $\mathrm{NaOH}, 2$ mmoles; and extract, in a total volume of $\mathrm{I} \cdot 5 \mathrm{ml}$. Following incubation at $37^{\circ}$, the reaction was stopped by the addition of I ml. $3 \mathrm{~N}-\mathrm{HClO}_{4}$. One ml. of $\mathrm{Fe}\left(\mathrm{ClO}_{4}\right)_{3}$ (O. Frederick Smith Chemical Co., Columbus, Ohio) in $\mathrm{O} \cdot \mathrm{I} \mathrm{N}-\mathrm{HClO}_{4}$ was then added, denatured protein removed by centrifugation, and the absorbance due to $\alpha-N$-acetyl- $\gamma$-Lglutamyl hydroxamate read at $510 \mathrm{~nm}$. Blank tubes were run in which the substrate was added only after stopping the reaction. A standard curve was constructed for $\gamma$-L-glutamyl hydroxamate (Sigma Chemical Co. Ltd, London).

Enzyme $\mathrm{C}$ was assayed essentially by the method of Baich \& Vogel (I962). The reaction mixture contained: glycine- $\mathrm{NaOH}$ buffer, $\mathrm{pH} 9.5,50 \mu$ moles; $\alpha$ - $N$-acetylglutamic $\gamma$-semi-

Table I. Bacterial strains

\begin{tabular}{|c|c|c|c|}
\hline Strain & Mating type & Relevant markers & $\begin{array}{l}\text { Source and/or } \\
\text { reference }\end{array}$ \\
\hline BL290* & $\mathbf{F}^{-}$ & his, trp & W. J. Brammar \\
\hline $6 P_{\ddagger}^{+}$ & $\mathbf{F}^{-}$ & his, ile, met, † pro & Baumberg (1970) \\
\hline $\mathbf{P 4 X} *$ & Hfr P4X & met $B \dagger$ & N. Glansdorff \\
\hline P4XB2 & Hfr P4X & met $B, \arg R$ & N. Glansdorff \\
\hline $\begin{array}{l}\text { MN42, EC(B), EC-I, } \\
\text { SupI02, CB-I }\end{array}$ & Hfr P4X & $\begin{array}{l}\text { met } B \text {, carrying deletions of } \\
\text { various parts of the } \\
\text { arg } E C B H \text { cluster }\end{array}$ & $\begin{array}{l}\text { N. Glansdorff; } \\
\text { Cunin et al. } \\
\text { (I969) }\end{array}$ \\
\hline BL29I & $\mathbf{F}^{-}$ & his, trp, argEI7I & See text \\
\hline BL292 & $\mathbf{F}^{-}$ & his, $\operatorname{trp}, \operatorname{argEI7} 6$ & See text \\
\hline BL293 & $\mathbf{F}^{-}$ & his, trp, argEI79 & See text \\
\hline BL294 & Hfr P4X & met $B, \arg E I 8 I$ & See text \\
\hline BL295 & $\mathbf{F}^{-}$ & his, ile, met, pro, argEII3 & See text \\
\hline BL332 & $\mathbf{F}^{-}$ & his, ile, met, pro, argEI62 & See text \\
\hline BL333 & Hfr P4X & $\operatorname{argEI} 8 I$ & See text \\
\hline BL334 & $\mathrm{F}^{-}$ & his, ile, pro, argEII3 & See text \\
\hline BL336 & $\mathbf{F}^{-}$ & his, ile, pro, argEI62 & See text \\
\hline BL 338 & Hfr P4X & $\operatorname{argEI} \mathrm{II}^{2}$ & See text \\
\hline BL350 & Hfr P4X & $\operatorname{argEI76}$ & See text \\
\hline BL 357 & Hfr P4X & $\operatorname{argEI79}$ & See text \\
\hline BL382 & Hfr P4X & $\operatorname{argEI} I_{3}$ & See text \\
\hline BL 397 & Hfr P4X & $\operatorname{argEI} 62$ & See text \\
\hline BL4O2 & Hfr P4X & $\arg E_{I 7 I}, \arg R$ & See text \\
\hline BL432 & Hfr P4X & $\arg E_{17} 6, \arg R$ & See text \\
\hline BL45I & Hfr P4X & $\arg E I 79, \arg R$ & See text \\
\hline BL470 & Hfr P4X & $\arg E_{I} 8 I, \arg R$ & See text \\
\hline BL478 & Hfr P4X & $\operatorname{argEII} 3, \arg R$ & See text \\
\hline BL483 & Hfr P4X & $\arg E_{1} 62, \arg R$ & See text \\
\hline
\end{tabular}


aldehyde, $\mathrm{I} \cdot 3 \mu$ moles; $\mathrm{K}_{2} \mathrm{HPO}_{4}, 40 \mu$ moles; NADP, $0 \cdot 25 \mu$ moles; bovine serum albumin, $1.5 \mathrm{mg}$; ; and extract, in a total volume of $1.5 \mathrm{ml}$. The increase in absorbance due to formation of $\mathrm{NADPH}_{2}$ was followed continuously with a Unicam SP 800 spectrophotometer. Some loss of enzyme activity occurred if the total protein concentration in the reaction mixture fell below I mg./ml.; this was prevented by the bovine serum albumin. $\alpha-N$-Acetylglutamic $\gamma$-semialdehyde was prepared according to Vogel \& McLellan (1970), except that it was eluted from the Amberlite IR-4B column with a $0.05-0.5 \mathrm{M}-\mathrm{K}_{2} \mathrm{SO}_{4}$ gradient. Fractions containing no 2-oxoglutarate were pooled, adjusted to $\mathrm{pH} 7 \cdot 0$ and stored at $-20^{\circ}$ till use. The presence of $\mathrm{K}_{2} \mathrm{SO}_{4}$ in the solution had no effect on the enzyme C assay. Material prepared and stored in this way became unusable after a few weeks; when such aged solutions were used, extracts known to be devoid of enzyme $\mathrm{C}$ activity gave an appreciable rate of $\mathrm{NADPH}_{2}$ formation in the assay.

Enzyme E was assayed by the method of Vogel \& Bonner (1956).

Enzyme $\mathrm{H}$ was assayed according to Theil, Forsyth \& Jones (I969), except that after the addition of $\mathrm{NaOH}$ to the assay mixture boiled with ninhydrin + citric acid each tube was shaken violently until all trace of blue colour had vanished. A further yellow colour due to argininosuccinate disappeared on standing for $2 \mathrm{~h}$. or was removed by placing the tubes in boiling water for $5 \mathrm{~min}$. Barium argininosuccinate was obtained from Sigma or was prepared by the method of Ratner (1957) using a protein extract of Escherichia coli W I60-37 $\left(\mathrm{F}_{14}{ }^{+}\right)$, a partial diploid for the $\operatorname{argECBH}$ cluster.

Protein was assayed by the method of Lowry, Rosebrough, Farr \& Randall (I95I).

Mutagenesis techniques and mutant isolation. Mutagenesis by $N$-methyl- $N$-nitro- $N$ nitrosoguanidine (NG) (Ralph N. Emanuel Ltd, London) followed the procedure of Adelberg, Mandel \& Chen (I965). Treated cultures underwent two or more cycles of penicillin enrichment for ornithine auxotrophs (Davis, 1948), before spreading on supplemented minimal agar plates + arginine ( $\mu \mathrm{g}$. $/ \mathrm{ml}$.). After incubation at $37^{\circ}$ for $48 \mathrm{~h}$., minute colonies (diameter 0.5 to $\mathrm{I} \mathrm{mm}$.) were selected for further study and frequently proved to be arginine auxotrophs.

In mutagenesis by the acridine half-mustard ICR I9I, an exponentially growing culture in supplemented minimal salts medium was diluted ( 100 to 300 cells $/ \mathrm{ml}$.) into several lots of similar medium + arginine. ICR I9I (kindly donated by Dr H. J. Creech, Institute for Cancer Research, Philadelphia) was added (Io to $25 \mu \mathrm{g}$. $/ \mathrm{ml}$.). All operations involving ICR I9I were carried out in a dark room under a red safety light, and the cultures, enclosed in aluminium foil, were incubated on an orbital incubator at $37^{\circ}$ for $48 \mathrm{~h}$. The culture that had grown at the highest ICR I9I concentration was then diluted and spread on supplemented minimal agar plates + arginine so as to obtain about 200 colonies per plate. These were replicated on to similar plates without and with arginine to identify $\mathrm{Arg}^{-}$colonies for further study. In some experiments, the ICR I9I-treated culture was subjected to penicillin enrichment and arginine auxotroph isolation as described above; however, with this technique no $\arg E$ mutants were obtained.

In reversion studies, supplemented minimal agar plates without arginine or a precursor were spread with $5-8 \times 10^{7}$ cells from a nutrient broth-grown culture washed with and resuspended in 0.1 M-potassium phosphate buffer. A drop of the mutagen (NG, $0.05 \mathrm{ml}$. of a $2 \mathrm{mg}$. $/ \mathrm{ml}$. aqueous solution; ICR-I9I, O.I ml. of a I00 $\mu \mathrm{g} . / \mathrm{ml}$. aqueous solution) was added to the centre of the plate. Plates were incubated at $37^{\circ}$ for 2 days.

\section{Transduction}

This was carried out according to Siegel \& Bryson (1967). 


\section{RESULTS AND DISCUSSION}

Isolation of mutants, reversion studies, and deletion mapping. We have collected $\mathrm{Arg}^{-}$ strains from six mutant isolation experiments in four of which we used ICR I9I to obtain frameshift mutations and in two, NG to provide base-substitution mutations for comparison. Starting strains were BL290 and P4X (for ICR I9I mutagenesis) and 6P (NG mutagenesis). Arginine auxotrophs obtained in these experiments were streaked on supplemented minimal medium containing acetylornithine, ornithine or arginine. The $\arg E$ mutants will grow on arginine but not on acetylornithine, and will also grow on ornithine if enzymes $F, G$ and $\mathrm{H}$ are present. It was reasoned that, although $\arg E$ polar mutations would diminish the level of enzyme $H$, they should still permit at least slow growth on ornithine, since even a strain, carrying a strongly polar $\arg B$ mutation, in which the activity of enzyme $\mathrm{H}$ is only I $\%$ of the wild-type maximum still shows very slow growth on ornithine (Cunin et al. 1969).

We therefore intended to examine arginine auxotrophs that failed to respond to acetylornithine but grew normally or slowly on ornithine. In fact, of the 23 mutants categorized (20 following ICR I9I and 3 following NG mutagenesis), all grew normally on ornithine. From each experiment, one such isolate was selected for further study; the isolates following ICR I9I treatment were denoted BL29I, BL292, BL293 (derived from BL290) and BL294 (derived from P4X) and those following NG treatment BL295 and BL332.

The mutants were tested for revertibility to arginine independence by ICR I9I and NG (Table 2). Each mutagen strongly reverts only the mutants obtained following its own use. These results provide strong presumptive evidence that BL29I, BL292, BL293 and BL294 carry frameshift arg mutations, and BL295 and BL332 base-substitution arg mutations. This is consistent with the appreciably higher spontaneous reversion rate of BL295 and BL332 (Oeschger \& Hartman, 1970). The slight revertibility of BL292 by NG is not contradictory since NG reverts frameshift mutations occasionally (Riyasaty \& Atkins, I968; Yourno \& Heath, 1969; Newton, 1970; Oeschger \& Hartman, 1970); the opposite event, reversion of a base-substitution mutation by an acridine half-mustard, is much rarer (Whitfield, Martin \& Ames, 1966; Berger et al. 1968), and was not observed for BL295 and BL332.

Evidence that the six mutations map in the $\arg E$ region was obtained by $\mathrm{PI} k c$ transduction. The donors were the mutants (BL29I, BL292 and BL293) or their met $^{+}$equivalents obtained by transduction (BL333, BL334 and BL336 from BL294, BL295 and BL332 respectively). The recipients were a series of derivatives of $\mathrm{P} 4 \mathrm{X}$ carrying various deletions extending into the $\arg E C B H$ cluster (Fig. 2).

The results are shown in Table 3. It is seen that the six mutants failed to yield $\mathrm{arg}^{+}$ recombinants when crossed with MN42, EC(B) or EC-I, but gave such recombinants when crossed with Sup 102 or CB-I. All six mutations therefore map in the region between the

Table 2. Reversion of ICR I9I- and NG-induced mutations by ICR I9I and NG

Reversion frequencies were obtained as described under Methods.

\begin{tabular}{llcc} 
& \multicolumn{3}{c}{ Mutagen } \\
Mutant & ICR I9I & NG & None (control) \\
BL29I & $>200$ colonies & 0 & 0 \\
BL292 & $>250$ & 3 & 0 \\
BL293 & $>200$ & 0 & 0 \\
BL294 & $>250$ & 0 & 0 \\
BL295 & 0 & $>200$ & 2 \\
BL332 & 0 & $>200$ & 4
\end{tabular}




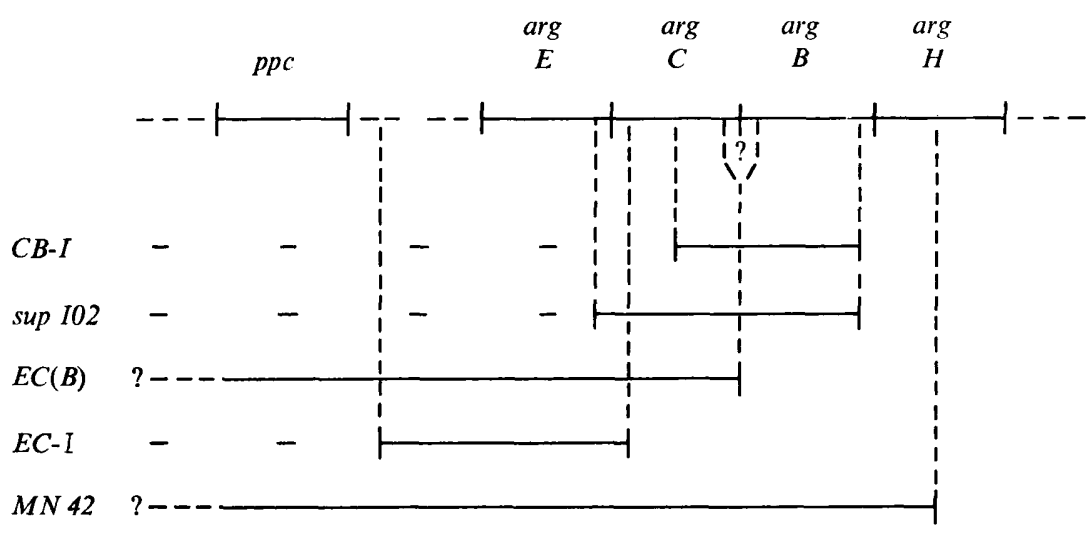

Fig. 2. The extent of deletions carried by derivatives of $\mathbf{P} 4 \mathbf{X}$ that were used in the approximate location of $\arg E$ mutations isolated in this study. The locus ppc controls the enzyme phosphoenolpyruvate carboxylase, closely linked to (and possibly contiguous with) $\arg E$. The evidence that sup 102 extends into $\arg E$ is biochemical and physiological (see Elseviers et al. 1969), and is not conclusive.

'left' end of $E C-I$ (which may lie outside the $\arg E$ structural gene) and the 'left' end of sup ro2. The mutations in BL29I, BL292, BL293, BL294, BL295 and BL332 were designated $E_{171}, E_{176}, E_{179}, E_{181}, E_{113}$ and EI62.

Arginine enzyme activities in the argE mutants. The $\arg R^{+}$strains BL338, BL350, BL357, BL382 and BL397, carrying $E_{I 7 I}, E_{I 76}, E_{I 79}, E_{I I} 3$ and $E_{I 62}$, and the $\arg R$ strains BL402, BL432, BL45I, BL470, BL478 and BL483, carrying $E_{I 7 I}, E_{I 76}, E_{I 79}, E_{I 8 I}, E_{I I 3}$ and $E_{I 62}$ respectively were constructed by $\mathrm{PI} k c$ transduction of $\mathrm{P} 4 \mathrm{X}$ and $\mathrm{P} 4 \mathrm{XB} 2$. These strains together with BL294 and their parents P4X and P4XB2 were grown in arginine-supplemented minimal medium and assayed for arginine enzymes as described in Methods. The results are presented in Table 4 .

It is clear that none of the $\arg E$ mutations is strongly polar, nor is there any consistent appearance of a weak polar effect (distal gene expression $50 \%$ or more of wild-type) if all the data are given equal weight. Since the enzyme C and B assays are less reliable than the enzyme $\mathbf{H}$ assay, particularly at low activities, we have calculated the ratio of enzyme $\mathbf{H}$ activity for each strain to that for the parent strain; if these values are consistently well below

Table 3. The ratio of arg ${ }^{+}$to met $^{+}$transductants (expressed as a percentage) from crosses between the putative argE mutants and various argECBH deletion mutants

\begin{tabular}{lllcrr} 
& \multicolumn{3}{c}{ Recipient } \\
\cline { 2 - 5 } Donor & MN42 & EC(B) & EC-I & Sup I02 & CB-I \\
BL29I & $<0.02 *$ & $<0.03$ & $<0.03$ & 5.4 & 5. I \\
BL292 & $<0.04$ & $<0.03$ & $<0.03$ & 7.5 & I4 \\
BL293 & $<0.04$ & $<0.03$ & $<0.04$ & 7.4 & 14 \\
BL333 & $<0.03$ & $<0.03$ & $<0.04$ & 6.3 & 9.2 \\
BL334 & $<0.03$ & $<0.01$ & $<0.06$ & I.I & 7.2 \\
BL336 & $<0.02$ & $<0.02$ & $<0.08$ & 8.0 & 4.6
\end{tabular}

* When no $\mathrm{arg}^{+}$recombinants were found, the ratio is given as less than that percentage which would have been calculated had one arg $^{+}$recombinant been obtained. 
I for a particular $\arg E$ mutation, the possibility of the mutation being polar must be considered. In fact, on this basis $E_{I 76}$ and $E_{I} 8 I$ might be claimed to be about 25 and $20 \%$ polar respectively (i.e. distal gene expression was lowered by these amounts).

Let us consider the implications of such an assertion. It could imply that $\operatorname{argECBH}$ is a single unit of transcription, and that of four frameshift mutations obtained, two showed no detectable polar effect while two showed polar effects of $25 \%$ or less. The implausibility of this is clear if we consider results obtained with other systems. Martin et al. (1966) reported that all of I4 Salmonella typhimurium LT2 hisC frameshifts were more than $50 \%$ polar; Newton (1970) found that of $3 \mathrm{I}$ Escherichia coli $\mathrm{KI} 2$ lacZ frameshifts, only 2 were less than $50 \%$ polar. Weakly polar nonsense mutations are similarly rare (Martin et al. 1966; Fink \& Martin, 1967; Zipser, Zabell, Rothman, Grodzicker \& Wenk, 1970).

It might be argued that our selection technique excludes extremely polar $\arg E$ mutations (enzyme $\mathrm{H}$ activity less than $\mathrm{I} \%$ of wild-type), implying that $\arg E$ polar mutations affecting the levels of enzymes $\mathbf{B}, \mathbf{C}$ and $\mathrm{H}$ do in fact occur, but are either extremely polar (over $99 \%$ ) or very weakly polar (less than $50 \%$ ). While this possibility cannot be ruled out, the $\arg E$ gene would be quite unique in this respect, for not only are such weakly polar mutations relatively uncommon, as pointed out above, but extremely polar mutations have not been encountered (Martin et al. I966; Newton, 1970) except when new genetic material has been inserted into the operon affected (Jordan, Saedler \& Starlinger, I968; Shapiro, 1969; Malamy, quoted in Newton, 1970). This is unlikely to result from ICR I9I treatment.

In view of the infrequency of weakly polar mutations in these systems, we believe the hypothesized isolation of four such frameshifts in $\arg E$ to be extremely improbable. We consider it more likely that the four $\arg E$ frameshift mutations do not exert a polar effect on $C, B$ and $H$, the observed variations in enzyme levels resulting from scatter in the measured activities or possibly small inter-strain differences; and that these results support the contention of Cunin et al. (1969) that $\arg E$ is not part of the same operon as $\operatorname{argC,B}$ and $H$.

Table 4. Specific activities ( $\mu$ moles product formed/mg. protein/h.) of enzymes coded for by genes argECBH in arginine-grown cultures of the argE mutants and of the parent strains

\begin{tabular}{|c|c|c|c|c|c|}
\hline \multirow[b]{2}{*}{$\arg R^{+}$Strains } & \multicolumn{4}{|c|}{ Enzyme } & \multirow{2}{*}{$\frac{\mathrm{H} \text { activity in mutant }}{\mathrm{H} \text { activity in parent }}$} \\
\hline & $\mathbf{E}$ & C & B & $\mathbf{H}$ & \\
\hline P4X & $4 \cdot 3$ & 0.10 & 0.09 & 0.22 & I \\
\hline BL338 & 0 & 0.19 & 0.18 & $0.3 \mathrm{I}$ & $\mathrm{I} \cdot 4$ \\
\hline BL350 & 0 & 0.08 & 0.17 & $0 \cdot 16$ & $0 \cdot 73$ \\
\hline BL357 & 0 & 0.13 & 0.20 & $0.3 \mathrm{I}$ & $\mathrm{I} \cdot 4$ \\
\hline BL 294 & 0 & 0.12 & 0.12 & 0.19 & 0.86 \\
\hline BL382 & 0 & 0.07 & 0.06 & 0.27 & $I \cdot 2$ \\
\hline BL397 & 0 & 0.10 & $0 \cdot 16$ & 0.20 & $0.9 I$ \\
\hline \multicolumn{6}{|l|}{$\arg R$ Strains } \\
\hline P4XB2 & $6 I$ & $2 \cdot 8$ & $2 \cdot 9$ & $7 \cdot 4$ & I \\
\hline BL4O2 & 0 & n.d.* & $2 \cdot 0$ & $4 \cdot 6$ & 0.62 \\
\hline BL432 & 0 & n.d. & $\mathrm{I} \cdot 7$ & $5 \cdot 5$ & 0.74 \\
\hline BL45 I & 0 & n.d. & $2 \cdot 8$ & 5.5 & 0.74 \\
\hline BL470 & 0 & n.d. & $2 \cdot 4$ & $5 \cdot 8$ & 0.78 \\
\hline BL 478 & 0 & $2 \cdot 7$ & 2.5 & 6.8 & 0.92 \\
\hline BL483 & 0 & $3 \cdot 2$ & $2 \cdot 3$ & $6 \cdot 6$ & 0.89 \\
\hline
\end{tabular}


We thank Miss Marion Baillie for able technical assistance, Drs N. Glansdorff and R. Cunin for the sharing of strains and information, Dr W. J. Brammar for strains and advice on ICR I9I mutagenesis, and Dr H. J. Creech for generously providing ICR I9I. E. A. was in receipt of a Science Research Council Research Studentship.

\section{REFERENCES}

Adelberg, E. A., Mandel, M. \& Chen, G. C. C. (1965). Optimal conditions for mutagenesis by $N$-methyl$N^{\prime}$-nitro- $N$-nitrosoguanidine in Escherichia coli KI2. Biochemical and Biophysical Research Communications 18, 788-795.

AsHCROFT, E. (1970). Studies on the arginine cluster in Escherichia coli K-I2. Ph.D. Thesis, University of Leeds.

BAICH, A. \& VoGeL, H. J. (1962). $N$-Acetyl- $\gamma$-glutamokinase and $N$-acetylglutamic $\gamma$-semialdehyde dehydrogenase: repressible enzymes of arginine synthesis in Escherichia coli. Biochemical and Biophysical Research Communications 7, 49I-496.

BaumberG, S. (1970). Acetylhistidine as substrate for acetylornithinase: a new system for the selection of arginine regulation mutants in Escherichia coli. Molecular and General Genetics 106, 162-173.

Berger, H., Brammar, W. J. \& Yanofsky, C. (1968). Spontaneous and ICR I9I-A-induced frameshift mutations in the $A$ gene of Escherichia coli tryptophan synthetase. Journal of Bacteriology 96, I672-1679.

Cunin, R., Elseviers, D., Sand, G., Freundlich, G. \& Glansdorff, N. (1969). On the functional organization of the argECBH cluster of genes in Escherichia coli K-12. Molecular and General Genetics ro6, 32-47.

DAvis, B. D. (1948). Isolation of biochemically deficient mutants of bacteria by penicillin. Journal of the American Chemical Society 70, 4267.

Elseviers, D., CUnin, R. \& GlansdorfF, N. (1969). Reactivation of arginine genes under the influence of polar mutations. FEBS Letters 3, I 8-20.

FinK, G. R. \& MARTIN, R. G. (1967). Translation and polarity in the histidine operon. II. Polarity in the histidine operon. Journal of Molecular Biology 30, 97-107.

GLANSDORFF, N. (1965). Topography of cotransducible arginine mutations in Escherichia coli K-I2. Genetics 5I, I67-179.

GlansDORfF, N., SAND, G. \& Verhoef, C. (1967). The dual genetic control of ornithine transcarbamylase synthesis in Escherichia coli K-I 2. Mutation Research 4, 743-75I.

Jordan, E., Saedler, H. \& Starlinger, P. (1968). $0^{\circ}$ and strong-polar mutations in the gal operon are insertions. Molecular and General Genetics 102, 353-363.

Lowry, O. H., Rosebrough, N. J., Farr, A. L. \& Randall, R. J. (195I). Protein measurement with the Folin phenol reagent. Journal of Biological Chemistry 193, 265-275.

MAAS, W. K. (196I). Studies on repression of arginine biosynthesis in Escherichia coli. Cold Spring Harbor Symposia on Quantitative Biology 26, 183-191.

MARTIN, R. G. (1967). Frameshift mutants in the histidine operon of Salmonella typhimurium. Journal of Molecular Biology 26, 3I I-328.

Martin, R. G., Whitfield, H. J., JUn., Berkowitz, D. B. \& Voll, M. J. (I966). A molecular model of the phenomenon of polarity. Cold Spring Harbor Symposia on Quantitative Biology 31, 21 5-220.

NewTON, A. (1970). Isolation and characterization of frameshift mutations in the lac operon. Journal of Molecular Biology 49, 589-60I.

OesChGER, N. S. \& HARTMAN, P. E. (1970). ICR-induced frameshift mutations in the histidine operon of Salmonella. Journal of Bacteriology 1or, 490-504.

Ratner, S. (1957). Preparation and determination of argininosuccinic acid. In Methods in Enzymology, vol. III, pp. 643-647. Edited by S. P. Colowick \& N. O. Kaplan. New York: Academic Press.

RIYASATY, S. \& ATKINS, J. F. (1968). External suppression of a frameshift mutant in Salmonella. Journal of Molecular Biology 34, 54I-557.

Shapiro, J. A. (1969). Mutations caused by the insertion of genetic material into the galactose operon of Escherichia coli. Journal of Molecular Biology 40, 93-105.

Siegel, E. C. \& Bryson, V. (1967). Mutator gene of Escherichia coli B. Journal of Bacteriology 94, 38-47.

TAYLOR, A. L. (1970). Current linkage map of Escherichia coli. Bacteriological Reviews 34, I55-I75.

THEIL, E. C., ForsYTH, G. W. \& JONES, E. E. (1969). Expression of the arginine regulon of Escherichia coli $\mathrm{w}$ : evidence for a second regulatory gene. Journal of Bacteriology 99, 269-273. 
Vogel, H. J., Baumberg, S., Bacon, D. F., Jones, E. E., Unger, L. \& Vogel, R. H. (1967). Gene-ribosomeenzyme organization in the arginine system of Escherichia coli. In Organizational Biosynthesis, pp. 223234. Edited by H. J. Vogel, J. O. Lampen \& V. Bryson. New York: Academic Press.

Vogel, H. J. \& BonNer, D. M. (1956). Acetylornithinase of Escherichia coli: Partial purification and some properties. Journal of Biological Chemistry 218, 97-106.

Vogel, H. J. \& McLellaN, W. L. (1970). $N$-Acetylglutamic $\gamma$-semialdehyde dehydrogenase (Escherichia coli). In Methods in Enzymology, vol XVII A, pp. 255-260. Edited by H. Tabor \& C. W. Tabor. New York: Academic Press.

Whitfield, H. J., Jun., MARTin, R. G. \& AMEs, B. N. (I966). Classification of aminotransferase ( $C$ gene) mutants in the histidine operon. Journal of Molecular Biology 21, 335-355.

Yourno, J. \& Heath, S. (1969). Nature of the hisD 3018 frameshift mutation in Salmonella typhimurium Journal of Bacteriology I00, 460-468.

Zipser, D., ZabelL, S., Rothman, J., Grodzicker, T. \& WeNK, M. (1970). Fine structure of the gradient of polarity in the $z$ gene of the lac operon of Escherichia coli. Journal of Molecular Biology 49, 25I-254. 